\title{
Induction of cellulose- and xylan-degrading enzyme systems in Aspergillus terreus by homo- and heterodisaccharides composed of glucose and xylose
}

\author{
Mária Hrmová, Eva Petráková and Peter Biely* \\ Institute of Chemistry, Slovak Academy of Sciences, Dúbravská cesta 9, 84238 Bratislava, Czechoslovakia
}

(Received 10 August 1990; revised 15 November 1990; accepted 21 November 1990)

\begin{abstract}
Synthetic heterodisaccharides composed of glucose and xylose were tested as inducers of cellulose- and xylandegrading enzymes in Aspergillus terreus, and the inducing abilities were compared with those of sophorose and xylobiose or their positional isomers. Measurement of secreted and cell-associated enzyme activities revealed that the heterodisaccharides induced the synthesis of the cellulolytic and xylanolytic enzymes, $2-O$ - $\beta$-D-glucopyranosyl D-xylose (Glc $\beta 1-2 X y l)$ being the most powerful inducer. Sophorose and 2-O- $\beta$-D-xylopyranosyl D-xylose (Xyl $\beta 1$ $2 \mathrm{Xyl}$ ), or their positional isomers, selectively induced the synthesis of cellulases and $\beta$-xylanases, respectively. An analysis of the extracellular enzymes (which were separated by isoelectric focusing followed by detection using chromogenic and fluorogenic substrates) showed that Glc/1-2Xyl initiated the synthesis of specific endo-1,4- $\beta$ glucanases and specific endo-1,4- $\beta$-xylanases identical to those produced separately in response to sophorose or Xyl $\beta 1-2 X y l$. Gle $\beta 1-2 X y l$ also induced specific endo-1,4- $\beta$-glucanases that hydrolysed 4-methylumbelliferyl $\beta$ lactoside at the agluconic bond. The results strengthen the concept of separate regulatory control of the synthesis of cellulases and $\beta$-xylanases. The results also suggest that mixed disaccharides, composed of glucose and xylose moieties, which may occur in nature, could play an important role in regulating the synthesis of wood-degrading enzymes.
\end{abstract}

\section{Introduction}

A generally accepted view on the regulation of synthesis of enzymes degrading polymeric substrates is that low constitutive levels of polysaccharide hydrolases interact with the polymer to produce small soluble 'signal' fragments, which enter the cell and induce the synthesis of the corresponding enzyme, thus permitting utilization of the polysaccharide (Reese, 1977; Sternberg \& Mandels, 1979). The most potent low-molecular-mass inducers of cellulase include sophorose, cellobiose and lactose (Mandels et al., 1962; Nisizawa et al., 1971), while those of $\beta$-xylanase comprise xylobiose and higher homologous xylooligosaccharides (Biely \& Petráková, $1984 a$; Hrmová et al., 1984) or non-metabolizable alkyland aryl- $\beta$-D-xylosides (Nakanishi et al., 1976; Biely et al., 1980). Another explanation for the induced synthesis of polysaccharide-degrading enzymes emphasizes a need for physical contact between the cell and the

\footnotetext{
Abbreviations: Umb-Lac, 4-methylumbelliferyl $\beta$-lactoside; 4-NPhLac, 4-nitrophenyl $\beta$-lactoside; HEC, hydroxyethylcellulose; OBRHEC, Ostazin Brilliant Red-hydroxyethylcellulose; RBB-xylan, Remazol Brilliant Blue-xylan.
}

polysaccharide (Berg \& Pettersson, 1977; Binder \& Ghose, 1978).

The principal components of wood include cellulose and hemicelluloses (e.g. xylans, mannans, xyloglucans, glucomannans, galactoglucomannans) cross-linked with lignin which are spread throughout the plant cell wall. Since the chemical structure of these natural wood composites is highly complex, the character of the true natural inducers of cellulases and $\beta$-xylanases in plants is obscure. These natural inducers may be represented not only by homodisaccharides such as cellobiose and xylobiose, but also by various heterodisaccharides, originating from (e.g.) xyloglucans. One such heterodisaccharide, $4-O-\beta$-D-xylopyranosyl L-arabinose, has been already tested in our laboratory for the production of xylan-degrading enzymes by the yeasts Trichosporon (Hrmová et al., 1984) and Cryptococcus (Biely \& Petráková, 1984a).

Using the homodisaccharides cellobiose (or its positional isomers) and xylobiose, we showed that the synthesis of cellulases and $\beta$-xylanases in Trichoderma reesei QM 9414 (Hrmová et al., 1986) and Aspergillus terreus (Hrmová et al., 1989) is under separate regulatory control. It was therefore of interest to investigate 
whether mixed disaccharides, such as glucosylxyloses and xylosylglucoses, would be able to induce both types of polysaccharide hydrolases in $A$. terreus. To our knowledge, such a complete group of these compounds has not been tested so far. Our aim was also to determine the substrate specificities and numbers of multiple enzyme forms of cellulases and $\beta$-xylanases induced by different disaccharides.

\section{Methods}

Chemicals. 2-O- $\beta$-D-Glucopyranosyl D-xylose (Glc $\beta 1-2 \mathrm{Xyl}$ ), 3-O- $\beta$-Dglucopyranosyl D-xylose (Glc $\beta 1-3 \mathrm{Xyl}$ ), 4-O- $\beta$-D-glucopyranosyl Dxylose (Glc $\beta 1-4 \mathrm{Xyl}$ ) and 4-O- $\beta$-D-xylopyranosyl D-glucose (Xyl $\beta 1-4 \mathrm{Glc}$ ) were prepared by the Helferich modification of the Koenigs-Knorr synthesis (Helferich \& Ost, 1962). The source of 2-O- $\beta$-D-glucopyranosyl D-glucose (Glc $\beta 1-2 \mathrm{Glc}$, sophorose), 3-O- $\beta$-D-glucopyranosyl Dglucose (Glc $\beta 1-3 \mathrm{Glc}), 4-O-\beta$-D-glucopyranosyl D-glucose (Glc $\beta 1-4 \mathrm{Glc}$, cellobiose), 6- $O-\beta$-D-glucopyranosyl D-glucose (Glc $\beta 1-6 \mathrm{Glc}$ ), $2-O-\beta$-Dxylopyranosyl D-xylose (Xyl $\beta 1-2 \mathrm{Xyl}$ ), 3-O- $\beta$-D-xylopyranosyl D-xylose (Xyl $\beta 1-3 \mathrm{Xyl}$ ), 4- $O-\beta$-D-xylopyranosyl D-xylose (Xyl $\beta 1-4 \mathrm{Xyl}$, xylobiose), 4-NPh-Lac, Umb-Lac and all other inducers and chemicals of p. a. purity is reported elsewhere (Hrmová et al., 1984).

Micro-organism and induction experiments. Aspergillus terreus strain F-413 was obtained from the Czechoslovak Collection of Microorganisms (Brno). Induction experiments were done as previously described (Hrmová et al., 1989) using 2 or $4 \mathrm{~mm}$ concentrations of saccharides tested as inducers in screening experiments and in time course studies, and $0 \cdot 6,2,4$ and $10 \mathrm{~mm}$ in concentration-dependence experiments. Each experiment was repeated at least three times; the standard deviation was not more than $\pm 20 \%$ of the mean.

Enzyme assays. The activity of cellulase was determined using filter paper (Mandels \& Weber, 1969) and that of endo-1,4- $\beta$-glucanase (EC 3.2.1.4) using HEC (Hrmová et al., 1984) following the liberation of reducing sugars. The activity of cellulolytic enzymes releasing aglycones from $\beta$-lactosides, referred to here as $\beta$-lactosidases, was assayed colorimetrically using 4-NPh-Lac (Hrmová et al., 1989) or fluorometrically (excitation at $340 \mathrm{~nm}$ and emission at $440 \mathrm{~nm}$ ) with Umb-Lac as described by van Tilbeurgh \& Claeyssens (1985). Endo-1,4$\beta$-xylanase ( $\beta$-xylanase; 1,4- $\beta$-D-xylan xylanohydrolase, EC 3.2.1.8), $\beta$-glucosidase ( $\beta$-D-glucoside glucohydrolase, EC 3.2.1.21), $\beta$-xylosidase ( $\beta$-D-xylan xylohydrolase, EC 3.2.1.37) and $\beta$-galactosidase ( $\beta$-Dgalactoside galactohydrolase, EC 3.2.1.23) were assayed on beechwood xylan, 4-nitrophenyl $\beta$-D-glucoside, 4-nitrophenyl $\beta$-D-xyloside and 4-nitrophenyl $\beta$-D-galactoside, respectively, as described previously (Hrmová et al., 1989). Total cell-associated $\beta$-glucosidase and $\beta$ xylosidase activities were determined using toluene-permeabilized cells as the enzyme source (Hrmová et al., 1984). All activities were determined in duplicate; reproducibility was $\pm 5 \%$.

One unit of enzyme activity is defined as $1 \mu$ mole of glucose or xylose equivalent, or as $1 \mu \mathrm{mol}$ of 4-nitrophenol or 4-methylumbelliferone, released per min from the appropriate substrate under the given conditions. $1 \mathrm{U}$ corresponds to 16.67 nanokatals.

Analysis of enzyme composition. Dialysed and lyophilized extracellular enzyme preparations, dissolved in distilled water (30-40 times more concentrated than those obtained after induction), were separated by analytical isoelectric focusing according to Radola (1980). Enzyme activities were detected by a zymogram technique using OBR-HEC, RBB-xylan and Umb-Lac as substrates (Biely et al., 1985; van Tilbeurgh et al., 1982; Biely \& Markovič, 1988). The pI values of enzyme components were determined by using standard pI marker proteins from Serva.

Test for hydrolysis and transformation of disaccharides. Hydrolysis of Glc $\beta 1-2 X y l, X y l \beta 1-2 X y l, X y l \beta 1-3 X y l$ and $X y l \beta 1-4 X y l$ was examined at $1 \mathrm{mM}$ concentration, and transformation of Glc $\beta 1-2 X y l$ at $40 \mathrm{~mm}$ concentration using Glc $\beta 1-2 \mathrm{Xyl}$-induced and non-induced toluenepermeabilized cells of $A$. terreus as the enzyme source. At intervals during $19 \mathrm{~h}$ incubation at $30^{\circ} \mathrm{C}$, aliquots were removed and centrifuged, and reducing saccharides were measured or analysed by thinlayer chromatography in supernatants (Hrmová et al., 1984).

Other methods. Concentration of disaccharides in the induction media was determined by the phenol-sulphuric acid method (Dubois et al., 1956). Reducing sugars were estimated by the Somogyi-Nelson procedure (Paleg, 1959) and protein content by the Lowry method using bovine serum albumin as the standard.

\section{Results}

Screening for induction by glucobioses, xylobioses, glucosylxyloses and one xylosylglucose

Fig. 1 contains structural formulae and abbreviations of compounds screened as inducers of cellulose- and xylandegrading enzyme systems in $A$. terreus with their corresponding extracellular enzyme activities. After $24 \mathrm{~h}$ incubation of the fungus with $4 \mathrm{~mm}$-saccharides, the endo-1,4- $\beta$-glucanase, $\beta$-lactosidase and endo-1,4- $\beta$-xylanase activities showed that $1,2-\beta$-linked homodisaccharides had selective inducing abilities. All the glucobioses, the best being Glc $\beta 1-2 \mathrm{Glc}$, induced the synthesis of endo-1,4- $\beta$-glucanase and $\beta$-lactosidase, but none induced the synthesis of endo-1,4- $\beta$-xylanase activity. On the other hand, the xylobioses Xyl $\beta 1-2 \mathrm{Xyl}$ or Xyl $\beta 1-3 \mathrm{Xyl}$ served as excellent inducers of endo-1,4- $\beta$-xylanase, but produced only low levels of endo-1,4- $\beta$-glucanase. Heterodisaccharides composed of glucose and xylose units behaved differently. As a rule, they served as hybrid inducers, promoting the synthesis of both cellulose- and xylan-degrading enzymes. Glc $\beta 1-2 \mathrm{Xyl}$ was the most efficient inducer, also initiating a high level of $\beta$-lactosidase activity. It is noteworthy that a certain activity, liberating a fluorogenic aglycone from UmbLac, was also recorded in the control enzyme samples (glucose or xylose medium or medium without inducer). This may indicate a constitutive production of the enzymes releasing 4-methylumbelliferone from the substrate. However, for unknown reasons, these activities were not found after the separation by isoelectric focusing followed by detection using Umb-Lac. $\beta$ Galactosidase activity was negligible in all cases, indicating that the hydrolysis of Umb-Lac was not due to a two-step reaction catalysed by $\beta$-galactosidase and $\beta$ glucosidase. 


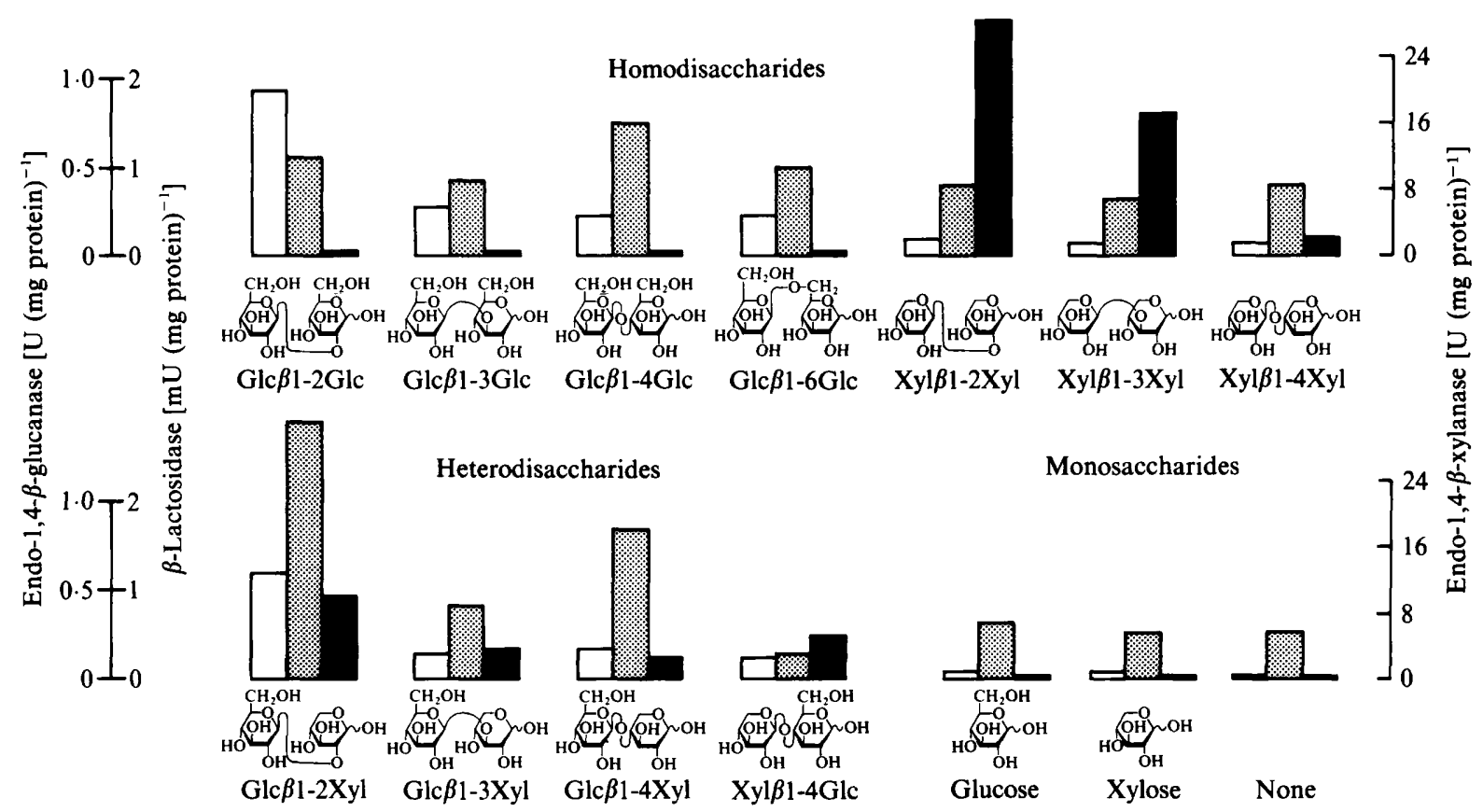

Fig. 1. Activities of extracellular endo-1,4- $\beta$-glucanase (open columns), $\beta$-lactosidase, assayed on Umb-Lac (dotted columns), and endo-1,4- $\beta$-xylanase (filled columns) of $A$. terreus after $24 \mathrm{~h}$ incubation with $4 \mathrm{~mm}$-homodisaccharides (glucobioses and xylobioses), heterodisaccharides (glucosylxyloses and xylosylglucose) and monosaccharides tested as the inducers. Structural formulae and abbreviations of the compounds are given. Values are given for a single experiment, but repetition yielded consistent results.

\section{Enzyme induction as a function of time}

The best inducers of extracellular cellulases and $\beta$ xylanases were $1,2-\beta$-linked disaccharides, i.e. Glc $\beta 1$ 2Glc among glucobioses, Xyl $\beta 1-2 \mathrm{Xyl}$ among xylobioses and Glc $\beta 1-2 X y l$ among glucosylxyloses. Therefore, further studies were performed using these compounds.

The results of time course studies of induction of cellulase and $\beta$-xylanase in $A$. terreus by $4 \mathrm{~mm}$-Glc $\beta 1$ 2Glc, $\mathrm{Xyl} \beta 1-2 \mathrm{Xyl}$ and Glc $\beta 1-2 \mathrm{Xyl}$ are shown in Fig. 2. These concentrations of the inducers were found to be optimal at about $2 \mathrm{mg}$ cell dry weight $\mathrm{ml}^{-1}$ (data not shown). It is clear from Fig. 2 that endo-1,4- $\beta$-glucanase activity appeared in the medium after $3 \mathrm{~h}$ in the presence of Glc $\beta 1-2 \mathrm{Glc}$ or Glc $\beta 1-2 \mathrm{Xyl}$, while extracellular $\beta$ lactosidase activity, induced by Glc $\beta 1-2 \mathrm{Xyl}$, increased without a lag. The activities of all extracellular enzymes induced by Glc $\beta 1-2 X y l$ were maximal after $9 \mathrm{~h}$ incubation, when only a low amount of Gic $\beta 1-2 X y l$ was detected in the medium (Fig. 3). The greatest $\beta$ lactosidase and cellulase activities on filter paper were detected in the presence of Glc $\beta 1-2 \mathrm{Xyl}$ (Fig. 2). On the other hand, the best inducer of endo-1,4- $\beta$-glucanase was Glc $\beta 1-2 \mathrm{Glc}$; however, very little $\beta$-lactosidase activity was found in this case. These results may explain the overall lower cellulase activity on filter paper detected in the presence of Glc $\beta 1-2 \mathrm{Glc}$. The time lag for the induction of endo-1,4- $\beta$-xylanase by $\mathrm{Xyl} \beta 1-2 \mathrm{Xyl}$ was about $3 \mathrm{~h}$ and thereafter the activity increased almost linearly. In the absence of the disaccharides, the specific activities of the polysaccharide hydrolases were less than $5 \%$ of the maximum levels.

In a further experiment, we tried to find out whether Glc $\beta 1-2$ Glc and Xyl $\beta 1-2 X y l$, present simultaneously in the medium, would be complementary to the inducing effect of Glc $\beta 1-2 X y 1$, i.e. whether they would induce the same spectrum of cellulolytic and xylanolytic enzymes. Therefore, Glc $\beta 1-2 \mathrm{Glc}$ and $\mathrm{Xyl} \beta 1-2 \mathrm{Xyl}$ were added together, each in $2 \mathrm{mM}$ concentration, to the medium. Fig. 2 shows that endo-1,4- $\beta$-glucanase, $\beta$-lactosidase, cellulase on filter paper and endo-1,4- $\beta$-xylanase activities appeared as before. However, the time course of production and yields of the enzymes were substantially different to those observed in the presence of Glc $\beta 1$ $2 X y l$. Clearly, no synergism was found between the effects of Glc $\beta 1-2$ Glc and Xyl $\beta 1-2 X y l$ with respect to the production of the cellulolytic and xylanolytic enzymes induced by Glc $\beta 1-2 \mathrm{Xyl}$. When both Glc $\beta 1-2 \mathrm{Glc}$ and $\mathrm{Xyl} \beta 1-2 \mathrm{Xyl}$ were tested at $4 \mathrm{~mm}$, the activities of all enzymes were lower than at $2 \mathrm{~mm}$ (data not shown), probably owing to a repression of enzyme synthesis.

Fig. 3 shows the time course of appearance of the extracellular and the total cell-associated $\beta$-glucosidase and $\beta$-xylosidase during $24 \mathrm{~h}$ incubation of $A$. terreus with 1,2- $\beta$-linked disaccharides. The maximum levels of total cell-associated $\beta$-glycosidases were reached in all 


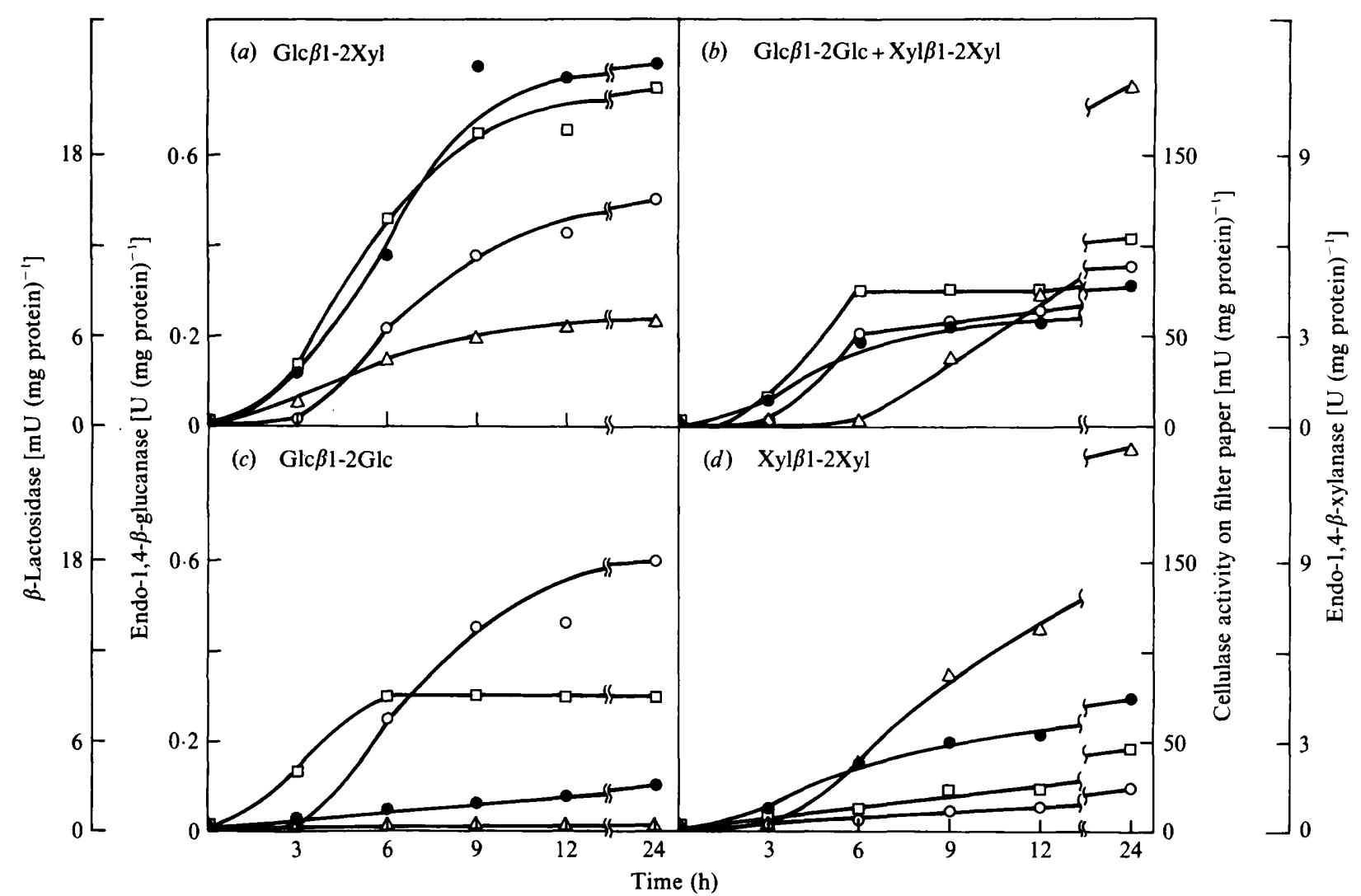

Fig. 2. Time course of induction of extracellular endo-1,4- $\beta$-glucanase (O), $\beta$-lactosidase, assayed on 4-NPh-Lac ( $)$, cellulase, using filter paper ( $\square$ ), and endo-1,4- $\beta$-xylanase $(\triangle)$ activities of $A$. terreus by (a) $4 \mathrm{mM}-\mathrm{Glc} \beta 1-2 \mathrm{Xyl}$, (b) Glc $\beta 1-2 \mathrm{Glc}$ and Xyl $\beta 1-2 \mathrm{Xyl}$ (both $2 \mathrm{~mm}$ ), (c) $4 \mathrm{mM}-\mathrm{Glc} \beta 1-2 \mathrm{Glc}$ and (d) $4 \mathrm{~mm}-\mathrm{Xyl} \beta 1-2 \mathrm{Xyl}$.

cases after about $6 \mathrm{~h}$ incubation, i.e. when the residual levels of the inducers amounted to about $10 \%$ of their original concentration. The extracellular $\beta$-glucosidase and $\beta$-xylosidase induced by the compounds tested increased steadily throughout the experiment and attained the highest values after $24 \mathrm{~h}$ incubation.

Analysis of cellulases and $\beta$-xylanases induced by Glc $\beta 1$ 2Glc, $X y l \beta 1-2 X y l$ and $G l c \beta 1-2 X y l$

Proteins secreted by $A$. terreus in response to the three selected 1,2- $\beta$-linked disaccharides were resolved by analytical isoelectric focusing. As shown in Figs 4(a) and $4(b)$, detection of the enzyme activities induced by Glc $\beta 1-2$ Glc and Xyl $\beta 1-2 X y l$ with OBR-HEC and RBBxylan revealed the presence of specific endoglycanases degrading cellulose and xylan. The same forms of specific endo-1,4- $\beta$-glucanases and specific endo-1,4- $\beta$ xylanases were induced by Glc $\beta 1-2 \mathrm{Xyl}$. However, one other group of specific endo-1,4- $\beta$-glucanases was also found (see below). The group of specific endo-1,4- $\beta$ glucanases hydrolysing exclusively HEC (thick arrows in Fig. 4a), detected also in the cellulose culture superna- tant (Hrmová et al., 1989), was represented by an alkaline (pI 7.7) and several acidic components (pI 6.6, and between 6.1 and 4.3 ). It is worth mentioning that the specific endo-1,4- $\beta$-glucanase with pI 6.1 was found to be produced in substantially different amounts in response to Glc $\beta 1-2 \mathrm{Glc}$ or Glc $\beta 1-2 \mathrm{Xyl}$ (white arrow in Fig. $4 a$ ). This may well be true also for some other forms of specific endoglycanases. The second group of specific endoglycanases (thick arrows in Fig. $4 b$ ), induced by $\mathrm{Xyl} \beta 1-2 \mathrm{Xyl}$ and Glc $\beta 1-2 \mathrm{Xyl}$, included alkaline endo-1,4$\beta$-xylanases (pI values between 9.6 and 7.8) and a neutral one (pI 6.5). The group of endo-1,4- $\beta$-glucanases (pI values 7.5 and 6.9), identified on the basis of OBR-HEC and Umb-Lac hydrolysis (thin arrows in Figs $4 a$ and $4 c$ ), was induced exclusively by Glc $\beta 1-2 \mathrm{Xyl}$. These enzymes, also present in the cellulose-spent growth medium, but in higher numbers of multiple enzyme forms (Hrmová et $a l ., 1989)$, were called specific endo-1,4- $\beta$-glucanases since they did not hydrolyse xylan, but they exhibited an affinity for Umb-Lac. It can therefore be said that the low hydrolytic activity on filter paper detected in the presence of Glc $\beta 1-2$ Glc (Fig. 2) was not due to the presence of different endo-1,4- $\beta$-glucanases from those 


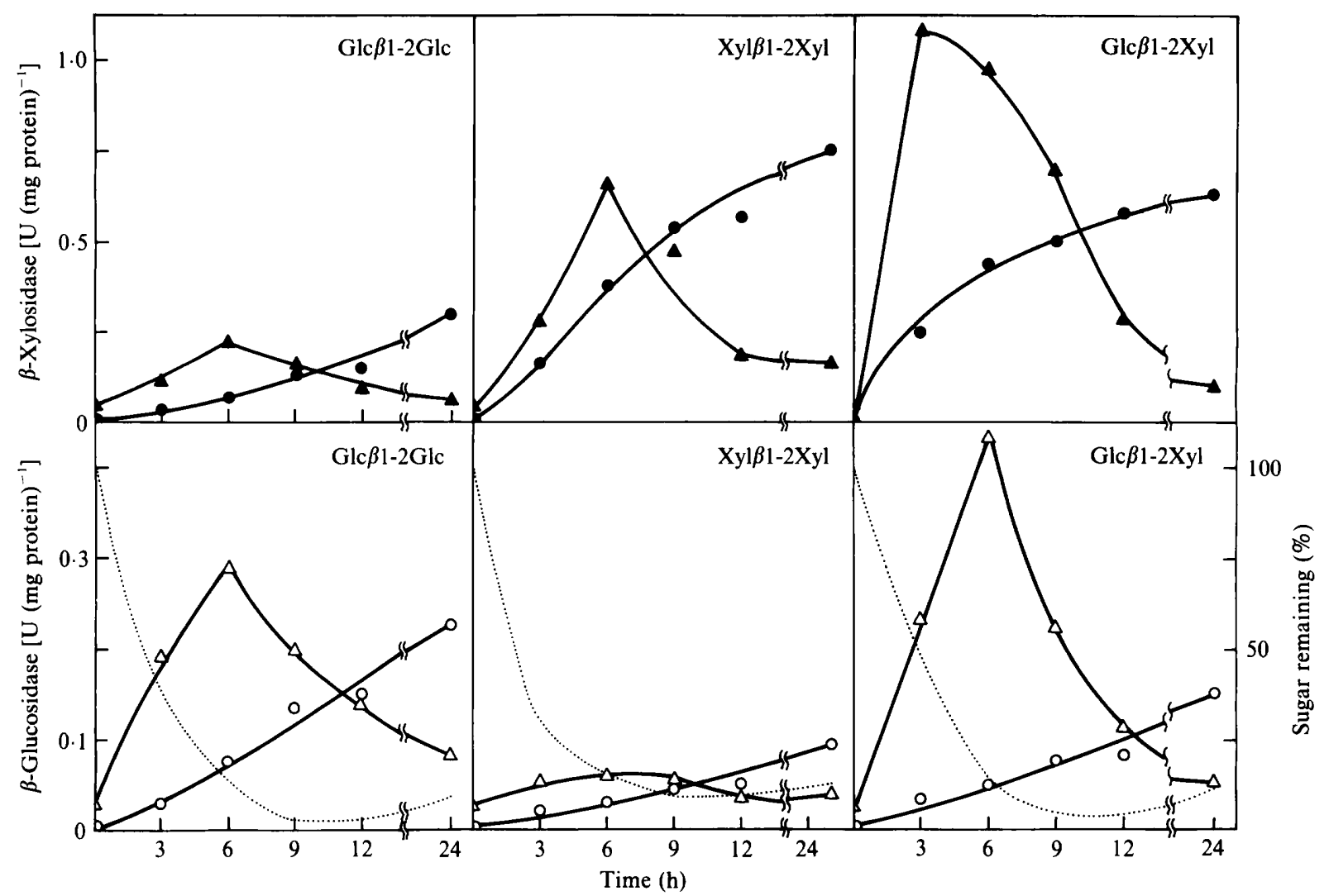

Fig. 3. Time course of induction of extracellular $(O)$ and total cell-associated $(\Delta) \beta$-glucosidase and extracellular $(\bullet)$ and total cellassociated $(\Delta) \beta$-xylosidase activities of $A$. terreus by $4 \mathrm{mM}$-disaccharides. Dotted lines show the level $(100 \% \equiv 4 \mathrm{mM})$ of disaccharides in the culture medium.

induced by Glc $\beta 1-2 \mathrm{Xyl}$, but rather due to the lack of specific endo-1,4- $\beta$-glucanases hydrolysing Umb-Lac at the agluconic bond.

\section{Fate of Glc $\beta 1-2 X y l$ in the induced cells}

It was of interest to investigate whether the inducing effect of Glc $\beta 1-2 X y l$ was due to its slower hydrolysis rate inside the cells or its transformation into some other active compound, as was shown with positional isomers of xylobiose in Cryptococcus albidus (Biely \& Petráková, $1984 b$ ). The former hypothesis was tested using cells induced by Glc $\beta 1-2 \mathrm{Xyl}$, which were permeabilized with toluene. Fig. 5 shows the kinetics of hydrolysis of Glc $\beta 1$ $2 \mathrm{Xyl}$ and of three xylobioses. It is clear that Glc $\beta 1-2 \mathrm{Xyl}$ was hydrolysed almost completely after $19 \mathrm{~h}$ by the Glc $\beta 1-2 X y l-i n d u c e d$ or even by the non-induced cells. The most resistant xylobioses were $\mathrm{Xyl} \beta 1-2 \mathrm{Xyl}$ and $\mathrm{Xyl} \beta 1-3 \mathrm{Xyl}$, which may explain their high capabilities for the induction of $\beta$-xylanase. The possibility that $40 \mathrm{mM} \mathrm{Glc} \beta 1-2 \mathrm{Xyl}$ is transformed into some other transglycosylation product was tested with Glc $\beta 1-2 \mathrm{Xyl}-$ induced cells (having specific activities of 35,97 and
$119 \mathrm{mU}$ (mg protein $)^{-1}$ for the total cell-associated $\beta$ xylosidase, $\beta$-glucosidase and $\beta$-xylanase, respectively). Thin-layer chromatography analysis of the products showed that the cell-associated enzymes only catalysed hydrolysis of Glc $\beta 1-2 \mathrm{Xyl}$ to glucose and xylose. It can therefore be concluded that, in the cells of $A$. terreus, Glc $\beta 1-2 \mathrm{Xyl}$ is hydrolysed but not transformed into any other transglycosylation product and that Glc $\beta 1-2 \mathrm{Xyl}$ may serve as a direct inducer of cellulases and $\beta$ xylanases.

\section{Discussion}

In the present work, our knowledge of the regulation of the synthesis of cellulose- and xylan-degrading enzyme systems in fungi was extended using a series of synthetic glucobioses, xylobioses, glucosylxyloses and one xylosylglucose. The synthesis of naturally occurring Glc $\beta 1$ 2Xyl had already been published (Jones \& Reid, 1960); however, the inducing capabilities of Glc $\beta 1-2 \mathrm{Xyl}$ and other related heterodisaccharides for cellulase and $\beta$ xylanase production were examined here for the first time. 
$\mathrm{pI}$

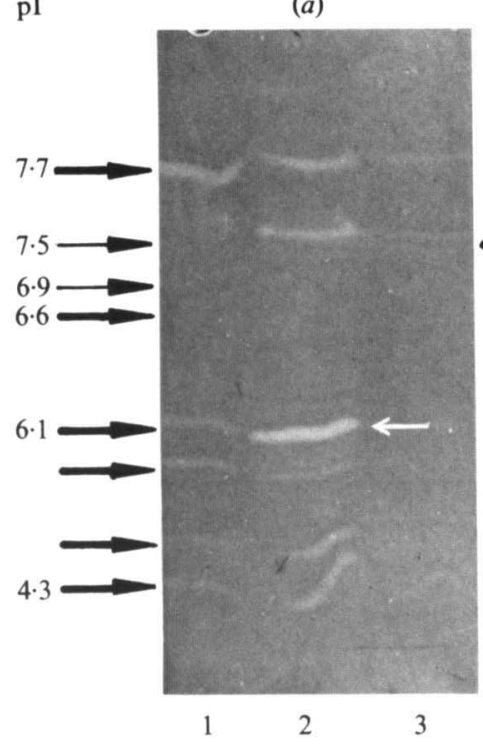

(b)

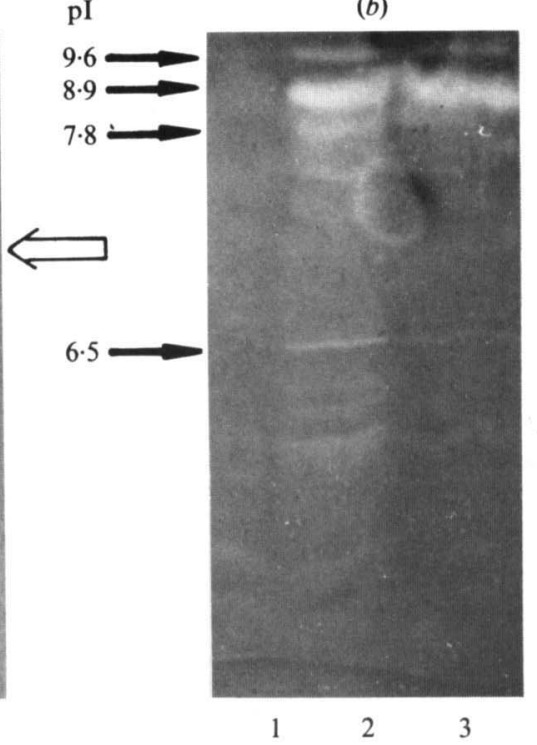

(c)

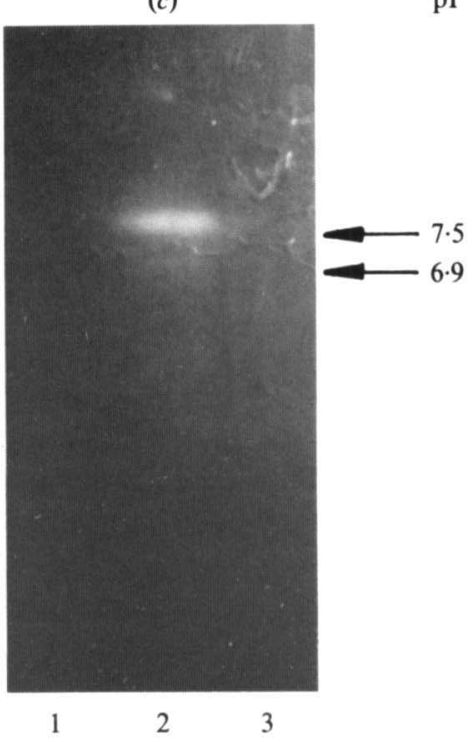

pI

Fig. 4. Endo-1,4- $\beta$-glucanases, endo-1,4- $\beta$-xylanases and $\beta$-lactosidases of $A$. terreus induced by $4 \mathrm{~mm}$-Glc $\beta 1$-2Glc (lane 1 ), Glc $\beta 1-2 \mathrm{Xyl}$ (lane 2) and Xyl $\beta 1-2 \mathrm{Xyl}$ (lane 3). The dialysed and lyophilized enzymes were prepared from cultures grown for $24 \mathrm{~h}$, and were resolved by isoelectric focusing ( $\mathrm{pH}$ span 3-10). The enzyme activities were detected by a zymogram technique using OBR-REC ( $a$, first replica from the separation gel), RBB-xylan ( $b$, first replica from the OBR-HEC detection gel) and Umb-Lac ( $c$, second replica from the separation gel). The large open arrow denotes the position of the sample application. The thick arrows pointing to panels $(a)$ and $(b)$ mark specific endo-1,4- $\beta$-glucanases and specific endo-1,4- $\beta$-xylanases, respectively. The thin arrows pointing to panels $(a)$ and $(c)$ mark specific endo-1,4- $\beta$-glucanases attacking both OBR-HEC and Umb-Lac. The white arrow in panel $(a)$ points to specific endo-1,4- $\beta$ glucanase induced by Glc $\beta 1-2 \mathrm{Xyl}$ which is synthesized in a larger amount than that induced by Glc $\beta 1-2 \mathrm{Glc}$. pI values for the main enzyme components are given near the arrows.

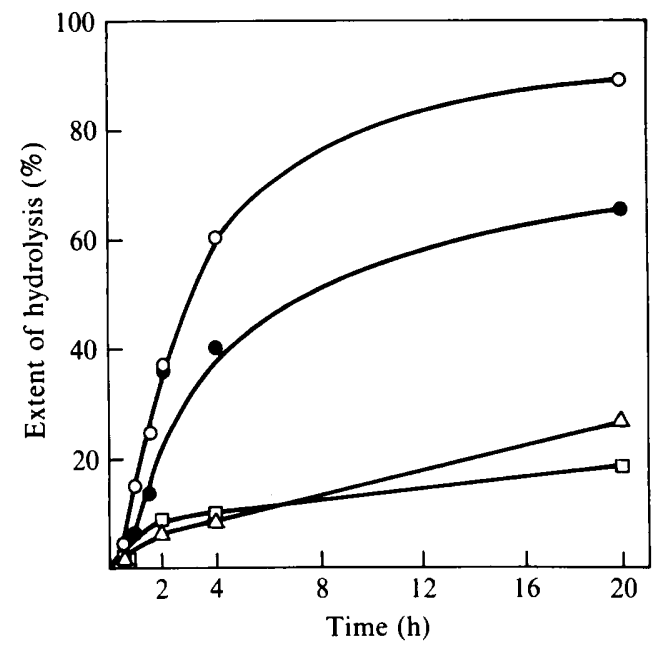

Fig. 5. Time course of Glc $\beta 1-2 \mathrm{Xyl}(O), \mathrm{Xyl} \beta 1-2 \mathrm{Xyl}(\triangle), \mathrm{Xyl} \beta 1-3 \mathrm{Xyl}$ $(\square)$ and $\mathrm{Xyl} \beta 1-4 \mathrm{Xyl}(\bullet)$ hydrolysis catalysed by Glc $\beta 1-2 \mathrm{Xyl}$-induced and permeabilized cells of $A$. terreus.

It was found with $A$. terreus that the mixed disaccharides, containing glucose and xylose moieties, were able to initiate the synthesis of both cellulase and $\beta$-xylanase. The substitution of xylose by glucose in the heterodisac- charide molecule led to $\beta$-xylanase and a group of specific endo-1,4- $\beta$-glucanases attacking HEC and UmbLac not being synthesized. On the other hand, $\beta$ xylanases (but not cellulases) were produced when xylobioses were applied. These findings support the concept of separate regulatory control of the synthesis of cellulases and $\beta$-xylanases, as was already suggested for T. reesei QM 9414 (Hrmová et al., 1986) and A. terreus (Hrmová et al., 1989).

The other important finding, that $1,2-\beta$-linked disaccharides, i.e. Glc $\beta 1-2$ Glc among glucobioses, $\mathrm{Xyl} \beta 1$ $2 \mathrm{Xyl}$ among xylobioses and Glc $\beta 1-2 \mathrm{Xyl}$ among glucosylxyloses, were the best inducers of cellulases and $\beta$ xylanases in $A$. terreus, is difficult to understand at present. Nevertheless, the results of this work indicate that, in $A$. terreus, transglycosylation reactions might give rise to positional isomers which could be more effective inducers than the oligosaccharides arising from polysaccharide hydrolysis. This has already been shown by Nisizawa et al. (1971) and Vaheri et al. (1979) for Trichoderma.

Resolution of the cellulolytic and xylanolytic enzymes induced by Glc $\beta 1-2 \mathrm{Xyl}$ revealed the presence of specific endo-1,4- $\beta$-glucanases and specific endo-1,4- $\beta$-xylanases which were identical to those produced separately in 
response to Glc $\beta 1-2 \mathrm{Glc}$ or $\mathrm{Xyl} \beta 1-2 \mathrm{Xyl}$. Glc $\beta 1-2 \mathrm{Xyl}$ was found to mimic the effects of both Glc $\beta 1-2$ Glc and $\mathrm{Xyl} \beta 1-2 \mathrm{Xyl}$ with respect to onset of the synthesis of specific endo-1,4- $\beta$-glycanases. However, Glc $\beta 1-2 \mathrm{Xyl}$ alone initiated the synthesis of another group of endo1,4- $\beta$-glucanases which also exhibited $\beta$-lactosidase activity. This observation could indicate that Glc $\beta 1$ $2 \mathrm{Xyl}$ interacts not only with the regulatory molecules for the synthesis of specific endo-1,4- $\beta$-glucanases as sophorose and xylobiose do, but also with other regulatory molecules which trigger the synthesis of endo-1,4- $\beta$ glucanases of a different type. In other words, in $A$. terreus, the synthesis of endo-1,4- $\beta$-glucanases with differing substrate affinities may not be under coordinate regulation by just one 'signal' molecule (Zhu et al., 1982), implying that a variety of 'signal' molecules may be required to initiate the synthesis of the complete spectrum of cellulases (Sternberg \& Mandels, 1979; Messner et al., 1988) produced during growth of $A$. terreus in cellulose-containing medium (Hrmová et al., 1989). Consistent with the results of the previous work (Hrmová et al., 1989), specific exo-1,4- $\beta$-glucanase, of the cellobiohydrolase I type found in Trichoderma (Hrmová et al., 1986), was not detected with Umb-Lac.

It is of interest that the group of heterodisaccharides examined cannot be regarded as universal inducers of cellulases and $\beta$-xylanases in fungi, since in $T$. reesei $\mathrm{QM}$ 9414, these compounds were ineffective (unpublished results). Differences among genera and species in this respect have already been observed. For example, sophorose, an excellent inducer of cellulase in the genus Trichoderma, was found to be less efficient in Schizophyllum commune (Rho et al., 1982) and in another basidiomycete isolated by Shewale \& Sadana (1978). Similarly, cellobiose failed to induce cellulase in some Trichoderma strains (Nisizawa et al., 1971; Sternberg \& Mandels, 1979; Royer \& Nakas, 1990).

\section{References}

Berg, B. \& Pettersson, G. (1977). Location and formation of cellulases in Trichoderma viride. Journal of Applied Bacteriology 42 , 65-75.

Biely, P. \& Markovič, O. (1988). Resolution of glycanases of Trichoderma reesei with respect to cellulose and xylan degradation. Biotechnology and Applied Biochemistry 10, 99-106.

Biely, P. \& Petrákoví, E. (1984a). Novel inducers of the xylandegrading enzyme system of Cryptococcus albidus. Journal of Bacteriology 160, 408-412.

Biely, P. \& Petráková, E. (1984b). Glycosidic bond rearrangements in isomeric xylobioses by yeast xylan-degrading enzymes. $F E B S$ Letters 178, 323-326.

Biely, P., KRátKÝ, Z., VRŠansKá, M. \& URmaničová, D. (1980). Induction and inducers of endo-1,4- $\beta$-xylanase in the yeast Cryptococcus albidus. European Journal of Biochemistry 108, 323-329.
Biely, P., Mislovičová, D. \& Toman, R. (1985). Soluble chromogenic substrates for the assay of endo-1,4- $\beta$-xylanases and endo-1,4- $\beta$ glucanases. Analytical Biochemistry 144, 142-146.

Binder, A. \& GHOSE, T. A. (1978). Adsorption of cellulase by Trichoderma viride. Biotechnology and Bioengineering 20, 1187-1199.

Dubois, M. K., Gilles, A., Hamilton, J. K., Rebers, P. A. \& Smith, F. (1956). Colorimetric method for determination of sugars and related substances. Analytical Chemistry 28, 350-356.

HeLFERICH, B. \& OST, W. (1962). Synthese eineiger $\beta$-D-Xylopyranoside. Chemische Berichte 95, 2612-2615.

Hrmová, M., Biely, P., Vršanská, M. \& Petráková, E. (1984). Induction of cellulose- and xylan-degrading enzyme complex in the yeast Trichosporon cutaneum. Archives of Microbiology 138, 371-376.

HRMOVÁ, M., BIELY, P. \& VRŠANSKÁ, M. (1986). Specificity of cellulase and $\beta$-xylanase induction in Trichoderma reese $\mathrm{QM} 9414$. Archives of Microbiology 144, 307-311.

Hrmová, M., Biely, P. \& VRŠAnSKÁ, M. (1989). Cellulose- and xylandegrading enzymes of Aspergillus terreus and Aspergillus niger. Enzyme and Microbial Technology 11, 610-616.

JONES, J. K. N. \& REID, P. E. (1960). The synthesis of 2-O- $\beta$-Dglucopyranosyl-D-xylose. Canadian Journal of Chemistry 38, 944-949.

MaNDELS, M. \& Weber, J. (1969). The production of cellulases. In Cellulases and their Applications, Advances in Chemistry Series 95, pp. 391-413. Edited by F. Gould. Washington: American Chemical Society.

Mandels, M., Parrish, F. W. \& Reese, E. T. (1962). Sophorose as an inducer of cellulase in Trichoderma viride. Journal of Bacteriology 83 , 400-408.

Messner, R., Gruber, G. \& Kubicek, C. P. (1988). Differential regulation of synthesis of multiple forms of specific endoglucanases by Trichoderma reesei QM 9414. Journal of Bacteriology 170, 36893693.

NaKanishi, K., Yasui, T. \& Kobayashi, T. (1976). Inducers for xylanase production by Streptomyces sp. Journal of Fermentation Technology 54, 801-807.

Nisizawa, T., Suzuki, H., Nakayama, M. \& Nisizawa, K. (1971). Inductive formation of cellulase by sophorose in Trichoderma viride. Journal of Biochemistry 70, 375-385.

PaleG, L. G. (1959). Citric acid interference in the estimation of reducing sugars with alkaline copper reagent. Analytical Chemistry 31, $1902-1904$.

RADOLA, B. J. (1980). Ultrathin-layer isoelectric focusing in 50-100 $\mu \mathrm{m}$ polyacrylamide gels on silanized glass plates or polyester films. Electrophoresis 1, 43-56.

REESE, E. T. (1977). Degradation of polymeric carbohydrates by microbial enzymes. In Recent Advances in Phytochemistry, pp. 311367. Edited by F. A. Loewus \& V. C. Runeckles. New York: Plenum Publishing Corporation.

Rho, D., Desrochers, M., Jurasek, L., Driguez, H. \& Defaye, J. (1982). Induction of cellulase in Schizophyllum commune: thiocellobiose as a new inducer. Journal of Bacteriology 149, 47-53.

ROYER, J. C. \& NAKAS, J. P. (1990). Interrelationship of xylanase induction and cellulase induction of Trichoderma longibrachiatum. Applied and Environmental Microbiology 56, 2535-2539.

Shewale, J. G. \& Sadana, J. C. (1978). Cellulase and $\beta$-glucosidase production by a basidiomycete species. Canadian Journal of Microbiology 24, 1204-1216.

SternberG, D. \& MANDELS, G. R. (1979). Induction of cellulolytic enzymes in Trichoderma reesei by sophorose. Journal of Bacteriology 139, 761-769.

van Tilbeurgh, H. \& Claeyssens, M. (1985). Detection and differentiation of cellulase components using low molecular mass fluorogenic substrates. FEBS Letters 187, 283-288.

van Tilbeurgh, H., Claeyssens, M. \& De Bruyne, C. K. (1982). The use of 4-methylumbelliferyl and other chromophoric glycosides in the study of cellulolytic enzymes. FEBS Letters 149, 152-156.

VAHERI, M., LEISOLA, M. \& KAUPINNEN, V. (1979). Transglycosylation products of cellulase system of Trichoderma reesei. Biotechnology Letters 1, 41-46.

Zhu, Y. S., Wu, Y. Q., Chen, W., Tan, C., GaO, J. H., Fei, J. X. \& SHIH, C. N. (1982). Induction and regulation of cellulase synthesis in Trichoderma pseudokoningii mutants $\mathrm{EA}_{3}-867$ and $\mathrm{N}_{2}-78$. Enzyme and Microbial Technology 4, 3-12. 